\title{
From Working in the Fields to Taking Control. Towards a Typology of Women's Decision-Making in Wheat in India
}

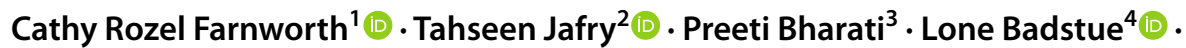 \\ Ashok Yadav $^{5}$
}

Published online: 5 June 2020

(๑) The Author(s) 2020

\begin{abstract}
Women in India perform a range of roles in wheat-based agricultural systems. However, data remain sparse. Cultural norms which construct men as farmers serve to conceal women's contributions from researchers and rural advisory services. We use data from communities in four Indian states, selected to exemplify high and low gender gaps, to provide insights into how women are challenging norms which privilege male decision-making in order to participate in innovation processes. We hypothesized the transitioning of women from labourers in wheat to innovators and managers of wheat is likely to be far from straightforward. We further hypothesized that women are actively managing the processes unleashed by various sources of change. We use the concept of doxa-ideas and actions in a society that are taken for granted and are beyond questioning - as an analytic lens to help us understand the ways in which women deploy their agency to secure their goals. Our analysis allows us to develop a 'A typology of women's strategies to strengthen their managerial decision-making power in wheat'.
\end{abstract}

Keywords Doxa $\cdot$ India $\cdot$ Feminization of Agriculture $\cdot$ Wheat $\cdot$ Empowerment

\section{Résumé}

En Inde, les femmes jouent divers rôles dans les systèmes agricoles basés sur la culture du blé. Cependant, les données restent rares. Les normes culturelles selon lesquelles ce sont les hommes les agriculteurs permettent de dissimuler la contribution des femmes aux chercheurs et aux services ruraux. Nous utilisons des données provenant de communautés de quatre États indiens, sélectionnées pour illustrer les écarts élevés et faibles entre les sexes, et pour fournir un aperçu de la façon dont les femmes défient les normes qui privilégient la prise de décision masculine afin de participer aux processus d'innovation. Nous avons émis l'hypothèse que pour les femmes, la transition du statut d'ouvrières dans la culture du blé au statut d'innovatrices et de gestion-

Cathy Rozel Farnworth

cathyfarnworth@hotmail.com

Extended author information available on the last page of the article

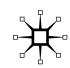


naires dans cette même filière sera certaintement loin d'être simple. Nous avons en outre émis l'hypothèse que les femmes gèrent activement les processus déclenchés par diverses sources de changement. Nous utilisons le concept de doxa - les idées et actions qui, dans une société, sont acquises et ne peuvent pas être remises en question - comme perspective d'analyse pour nous aider à comprendre comment les femmes utilisent leurs capacités pour atteindre leurs objectifs. Notre analyse nous permet de développer une «Typologie des stratégies des femmes pour renforcer leur pouvoir décisionnel en tant que gestionnaire dans la culture du blé».

JEL Codes $\mathrm{I} 30 \cdot \mathrm{I} 31 \cdot \mathrm{N} 55 \cdot \mathrm{O} 20 \cdot \mathrm{O} 30 \cdot \mathrm{O} 35 \cdot \mathrm{Q} 10 \cdot \mathrm{Q} 12 \cdot \mathrm{R} 20$

\section{Introduction}

India is the second largest producer and consumer of wheat globally, and wheat is its second most important staple food crop, after rice (USDA 2017). New, increasingly climate-smart, technologies in wheat are widely promoted. Among others, they include improved wheat varieties, zero tillage, residue management, seed drillers, laser land levelling, and combine harvesters. These technologies eliminate weeks and even months of arduous labour and hold the promise of increased productivity and production (Aryal et al. 2018; Jat et al. 2014; Chauhan et al. 2012).

Despite the importance of wheat to livelihoods and food security literature searches and stakeholder discussions conducted across the Indo-Gangetic Plains (IGP) covering India, Bangladesh, Nepal and Pakistan indicate that data on the roles and responsibilities of women in wheat is sparse (Badstue et al. 2017; Jafry 2016). Drucza and Peveris (2018) review 73 papers about women in wheat-based systems in Pakistan. They find that the literature strongly reasserts "cultural norms and gender roles [in agriculture], rather than question their persistence or attempt to examine them. The binary thinking which simplistically identifies men with technology and farming, and women with tradition and home, accompanies much gender-blind work." Jafry $(2016,2013)$, in literature reviews of gender and wheat across the IGP, comes to much the same conclusion. Farnworth and Colverson (2015) coined the term 'conceptual lock-in' to describe the phenomenon of research centres, policymakers, the rural advisory services (RAS) and even farming families themselves constructing farmers as male-regardless of the reality of female farmers on the ground. In India, the word kisan (farmer) is strongly identified with men farmers (Aryal et al. 2014). Rao (2012) provides a case study from Uttar Pradesh in which she reflects on the strange phenomenon of women busy in the fields from the early hours and self-evidently watering and weeding wheat yet neither men nor women acknowledging this as happening. In discussions, men speak of their work in the wheat fields and women of their work at home. "What one saw seemed almost the opposite of what one heard" (ibid., p. 1044). Landesa and Oxfam (2013) argue that the imagery of the farmer as male helps legitimatize 
male rights over physical and financial capital, including control over and access to land, as well as less tangible capitals such as decision-making power, and the right to participate in information networks.

Despite deep-seated and often unquestioned social norms that privilege men as agricultural decision-makers and breadwinners women are indeed strongly involved in different aspects of wheat cultivation and decision-making across the IGP (Farnworth et al. 2018; de Neve 2017; Jafry 2013; Sinha et al. 2012; Rao 2011; Agarwal 1997). Furthermore, the broader literature on agrarian change suggests that a feminization of agriculture is well underway, including in India, the focus of this article. Gartaula et al. (2012) usefully distinguish between labour feminization of agriculture and managerial feminization of agriculture, with the latter term indicating that women have a strong decision-making role and the capacity to be change makers. We add that rather than seeing these two states as a dichotomy, the process can be best conceptualized as a kind of messy continuum, with women exerting various forms of decision-making power at various points along the continuum (Farnworth et al. 2018).

With respect to labour feminization processes, there is strong evidence that the proportion of women, relative to men, in field labour has increased over the past few decades (Ghosh and Ghosh 2014; Guérin 2013; Chayal and Dhaka 2010; Garikipati 2008; Verma 1992; Shiva 1991). Pattnaik et al. (2017) analyse four sets of occupational data drawn from the Indian Census (1981, 1991, 2001 and 2011). Table 1 indicates that agriculture as a source of employment has shrunk by $15.8 \%$ over the past forty years with men leaving at higher rates than women. In 2011 half of all male workers in 2011 were working in agriculture, compared to around two-thirds of women (ibid.).

Various explanations have been put forward as to why women dominate the agricultural workforce. The literature broadly suggests that men-though their opportunities are strongly affected by caste-experience higher agency and enjoy higher mobility than women, allowing them to respond more effectively than women to the pull factors of economic opportunity and the push factors of rural stagnation. This contributes to higher rates of male outmigration, both short and long-term, and a greater ability to seize more local off-farm employment opportunities (De Neve 2017; Saha et al. 2018; Da Corta and Venkateshwarlu 1999).

Can we assume that feminization processes mean that women are taking more managerial decisions in agriculture? Pattnaik et al. (2017) argue that there is no necessary correlation between men leaving agriculture and women left behind

Table 1 Absolute percentages of men and women working in agriculture in India (19812011). Source Adapted from Pattnaik et al. (2017)

\begin{tabular}{llll}
\hline Census year & Male (\%) & Female (\%) & $\begin{array}{l}\text { Agricultural (\%) vis-à-vis } \\
\text { non-agricultural employ- } \\
\text { ment }\end{array}$ \\
\hline 1981 & 66.3 & 82.6 & 70.3 \\
1991 & 60.9 & 82.4 & 67.2 \\
2001 & 51.9 & 71.8 & 58.4 \\
2011 & 49.8 & 65.1 & 54.5 \\
\hline
\end{tabular}


on the farm experiencing higher decision-making capacity. Indeed, rather than a feminization of agriculture the correct term for this process, they contend, is the feminization of agrarian distress (ibid.). Sinha et al. (2012) consider that male outmigration conserves traditional kinship structures and patriarchal/seniority values by pushing wives back into the extended family since Indian society rarely tolerates married women living alone. This can have the effect of reducing the agency of left-behind wives, particularly if decision-making is passed from the husband to other male relatives. Even so, their research suggests that some leftbehind wives are increasing their decision-making power, though they do not consider this effect to be widespread (ibid.). In Bihar, an examination of intra-household decision-making shows that technologies are adopted when they reduce male labour in the field or reduce the cost of hired labour. Although women make the case for technologies which save women's labour, their intra-household bargaining power relative to men's is too weak to affect the final choice of technologies households choose to adopt (Gulati 2016). In Karnataka, Goudappa et al. (2012) find that women are increasingly participating in agricultural decision-making though the 'final decision' rests with men.

It is with these complex findings in mind, and with respect to the paucity of data on women in wheat, that this paper explores the extent to which social norms in selected locations in India's wheat belt are shifting to accommodate recognition of women as wheat farmers and innovators and as farm managers. We have two analytic starting points.

- First, we hypothesize that due to strong cultural norms which privilege male agency, the transitioning of women from labourers in wheat to innovators and managers of wheat is likely to be far from straightforward.

- Second, we hypothesize that women are actively managing the processes unleashed by various sources of change.

To test our hypotheses, we develop a Conceptual Framework. The starting point of the framework is Bourdieu's (1977) concept of 'doxa'. Doxa, discussed in more detail below, can be summarized as ideas and actions in a society that are taken for granted and are beyond questioning (ibid.). In our case, the primary doxa which women may be challenging — or be unable to challenge - is that men take decisions in wheat farming. This is part of the construction of kisan-men are farmers, not women. We use our Conceptual Framework to explore the findings from fieldwork conducted in 2015 in six wheat-growing communities in four states (Bihar, Uttar Pradesh, Haryana and Punjab). The aim of the fieldwork was to examine the ways in - and the degree to which — women and men farmers are able to innovate, and to assess how locally valid gender norms affect their capacity to do so.

Our Conceptual Framework allows us to analyse the research findings in a novel way. Rather than report on gender differences between women and men in innovation capacity, for instance, or discuss the relative importance of wheat compared to other agricultural innovations to livelihoods, we use the Conceptual Framework to elicit the strategies women in 'low' and 'high' gender gap (which we define further below) communities use to take managerial control over decision-making in wheat. 
This analytic process allows us to develop a typology of women's strategies which we call: 'A typology of women's strategies to strengthen their managerial decisionmaking power in wheat' (Fig. 2). Potential strategies range from a zero point (no strategy, the woman is fully immersed in the doxa that men take all decisions) through to the emergence of a new doxa, which is that women take all decisions.

Constructing a typology is valuable, because it allows us to lift what women say about their lives and how they set goals out of the realm of the merely anecdotal and to start systematizing them in a logical way. Cornwall (2016) highlights the importance of understanding the 'hidden pathways' that women travel on their journeys towards empowerment. We see our approach as allowing women's strategizing on hidden pathways to become visible. Importantly, our framework emerges from the research findings, and does not precede it. In other words we have not pre-set potential types of strategy and then attempted to assign women's responses accordingly. We feel that we simply do not have the prior knowledge to do this. Furthermore, this approach has the advantage of allowing us to foreground the emic insider understandings the women hold about their own realities (Rapley 2003). We learn from the women themselves about their strategies and how they relate them to the cultural norms shaping the societies within which they live. In other words, our approach acknowledges the "shifting, relational nature of gender, and the active role of men and women in constructing their identities, in 'doing gender" (Farnworth 2007). It is only during analysis that we-the outsiders-start to cluster these strategies and to relate them to how women work with local norms. It is our hope that researchers trying to understand empowerment dynamics and how to think about women's agency will find our typology useful and experiment further with it. Other development partners, on the basis of our framework, should be able to more readily perceive that women develop a range of strategies that they carefully nuance, and which they own. Such strategies can be sensitively supported but they must be left in the hands of the women themselves to manage.

The remainder of the article proceeds as follows. We set out our conceptual framework. We then describe our research methods and present the six study communities. These study communities are categorized as 'low gender gap' and 'high gender gap', three in each. The findings are presented within each broad category according to type of respondent (middle-income, low-income, young women) and we add findings on the degree to which locally important institutions-Rural Advisory Services (RAS) and village heads (and shopkeepers)—recognize and respond to women's strategizing. Our typology is then presented and discussed. Figure 1 sets out our analytic approach in this article.

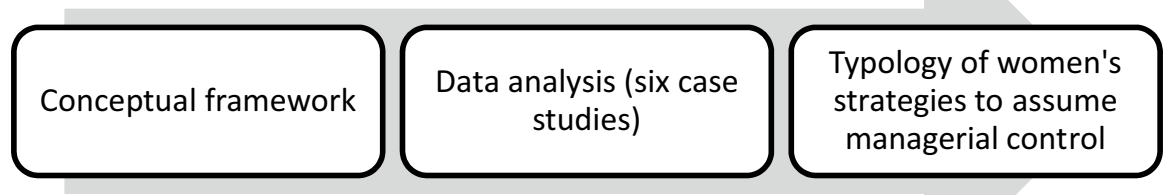

Fig. 1 Analytic trajectory of the article

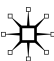




\section{The Conceptual Framework: Doxa as an Analytical Lens}

Cohen et al. (2016) define capacity to innovate as the ability to deliberatively transition or transform a system from its current state to a new state. The freedom of the actor to respond, or to take charge, is assumed. Our analytic starting point is that 'freedom to act' is partly contingent on social norms that facilitate or limit freedoms. Social norms are constituted of (usually) unwritten codes and informal understandings that define what we expect of other people and what they expect of us. They include a wide constellation of behaviours. They define, for example, how to dress, obligations to family members, expected responses to property rights, and concepts of right and wrong (Young 2015). Whilst social norms are clearly contingent on location and historical time, some are 'so embedded in our ways of thinking and acting that we $[\ldots]$ follow them unconsciously and without deliberation, hence we are sometimes unaware of how crucial they are to navigating social and economic relationships' (ibid:3). This is close to the formulation of doxa proposed by Bourdieu (1977). Doxa denotes what is taken for granted in a particular society, the experience by which 'the natural and social world appears as self-evident'. A practice 'goes without saying because it comes without saying' (Bourdieu 1977, p. 167). Doxa can be understood as a kind of unquestioned truth which people live by.

Although doxa may appear self-explanatory and natural, they are far from neutral in their application and effects. Doxa may favour, serve and maintain the conditions for interests (economic, social, other) important to a specific group which may result in harms of one kind or another to another group. For example, doxa may favour the interests of a certain caste above other castes, one ethnicity above another, one sexual orientation above another, one gender above another, and so on. Some doxa draw their legitimacy from religious or other beliefs (Agarwal 1997) but many doxa have no easily identifiable ethical basis or other justification (Stewart 2013).

A widely acknowledged starting point for empowerment processes is an awareness by disadvantaged people of their disadvantaged state. For example, Kabeer (1999) argues that one way of thinking about power is in terms of the ability to define one's goals and-critically-act upon them. In this formulation, awareness is taken for granted, as if people have an objective understanding of their (disempowered) state and the extent of their agency. This is the starting point for Kandiyoti (1988) who suggests that women strategize within a set of specific constraints. Different forms of patriarchy, specific to time and place, present women with distinct 'rules of the game' and call for different strategies to maximize security and optimize life options with varying potential for active or passive resistance in the face of oppression.

Bourdieu (1977) claims, however, that an objective understanding of one's state is not fully possible. No one can experience complete autonomy from doxa because our choices are shaped by who we are at a specific historical juncture and in a specific place. We cannot stand entirely outside our historical selves. Thus, our personhood is intrinsically interwoven with doxa. Bourdieu terms this habitus. In relation to women's empowerment, habitus plays an important role in shaping a woman's character, beliefs, preferences and choices, and in framing her conceptualization of 
what the process towards - and the achieved state of - empowerment might actually look like. The idea of habitus suggests that there are boundaries or limits beyond which a person cannot act or think (Risseeuw 2005).

Nevertheless, wider changes in society can force hitherto unseen and unremarked doxa to become visible. Formerly unquestioned norms become open to being talked about, discussed and challenged. However, since doxa, as noted above, usually serve particular interests, groups which have benefited from doxa may stage a backlash. One reaction by dominant groups is to codify doxa, once it has become visible, in orthodoxy. Orthodoxy imposes an opposition between right and wrong interpretations of doxa and thus aims to limit discourse and challenge. In extreme cases, this process may lead to religious dissenters, for example, being branded heretics (Qadir 2015).

However, the doxic boundary can be patrolled less dramatically through the deployment of descriptive and injunctive norms (Ball Cooper and Fletcher 2012). Descriptive norms refer to beliefs about what constitutes normal practice in a given group (ibid.). For instance, women and men may seek to enact culturally appropriate norms of a 'good wife' and a 'good husband' and to rear their children to take on these roles in adulthood. Co-performance of stereotypical gender roles, in some cases, contributes to upholding a particular social order which both women and men feel it is necessary to maintain, though not necessarily for the same reasons (Rao 2012). Injunctive norms refer to beliefs about what people in a given group should do (Ball Cooper and Fletcher 2012). Compliers with these beliefs may be positively sanctioned, for instance by being praised or accepted by the group whereas noncompliers risk being negatively sanctioned, for example through gossip, isolation and even death (Cislaghi and Heise 2017).

The role of descriptive and injunctive norms and sanctions appears to be to maintain doxa in an unchanged state. However, doxa are in fact not static. Risseeuw (2005) highlights the historical nature of doxa, showing how they are continually reinvented in response to changes in the wider environment. In some cases, doxa may mutate so subtly and incrementally that these processes of change are scarcely perceived, and in time even awareness that doxa have changed is lost. She argues, using a case study of Sri Lanka under colonial rule, that gender relations with regard to property were imperceptibly transformed over time such that concepts of access, control and ownership which would have appeared to one generation as unthinkable came to seem normal or obvious to later generations. However, these changes actually resulted in a considerable undermining of women's entitlements over the space of a century or so. Risseeuw notes that no one actively sought to diminish women's previously strong rights to property, rather than it seemed necessary, in the struggle of elite Sinhalese men against colonial rule, for their wives and daughters to accept the merging of their individual rights to property with those of their spouses. Behaving otherwise would have been seen as weakening the family's interests as a whole. Women, Risseeuw considers, were aware that they were losing their specific rights but they silently acquiesced. They did so because the changes seemingly took place for other reasons, in particular the struggle against colonialism. At the time these changes were not perceived as creating a transformation of power relations between 
the sexes which would lead to women becoming disadvantaged in relation to men over time (ibid.).

We take these insights from the literature on norms and doxa into our analysis of our fieldwork data. We show how middle- and low-income women are reconsidering and attempting to reshape their participation in decision-making processes. We discuss how men react, and we examine whether local institutional actors are recognizing how women are changing, and whether this recognition affects women's ability to innovate in wheat.

\section{Research Design}

\section{Method}

The GENNOVATE (Enabling Gender Equality in Agricultural and Environmental Innovation) research project researched gender norms and dynamics in wheat innovation processes in twelve communities across India in 2015. The methodology builds on GENNOVATE research protocols (Petesch et al. 2018). Community selection was based on a purposive, maximum diversity sampling approach guided by two criteria considered significant for assessing gender differences in agricultural innovation: (i) gender gaps in resources and capacities and (ii) economic dynamism. Gender gaps are gauged with reference to indicators such as women's leadership, physical mobility status, education levels, access to and control over productive assets, and the ability to market and to benefit from sales of agricultural produce. Economic dynamism is estimated using indicators such as infrastructure development, the integration of local livelihood strategies with markets, labour market opportunities, and resources available to local communities for innovations in agriculture.

To reduce the number of variables under consideration, we examine the strategies of women engaged with wheat agriculture in low and high gender gap communities in the context of high economic dynamism. This provides us with six case studies in four states (Table 2). The names of the communities have been changed.

The research teams carried out 15 sex-disaggregated data collection activities in each community (Table 3). Sex-disaggregated focus group discussions (FGD) were conducted with low-income women and men, the second with middle-income women and men, and the third with young women and men (resulting in six FGDs per community). A further nine semi-structured interviews (SSI) were conducted in each location: (i) a community profile with men and women key informants to obtain local demographic, social, economic, agricultural, and political information, (ii) innovation pathway interviews with two men and two women known for trying new things in agriculture, and (iii) life story interviews, likewise conducted with two men and two women. In total, 191 men and 212 women participated in the research in the six selected sites.

Although all data collection was disaggregated by gender, respondents were not further disaggregated by caste. However, examining respondent names show that 


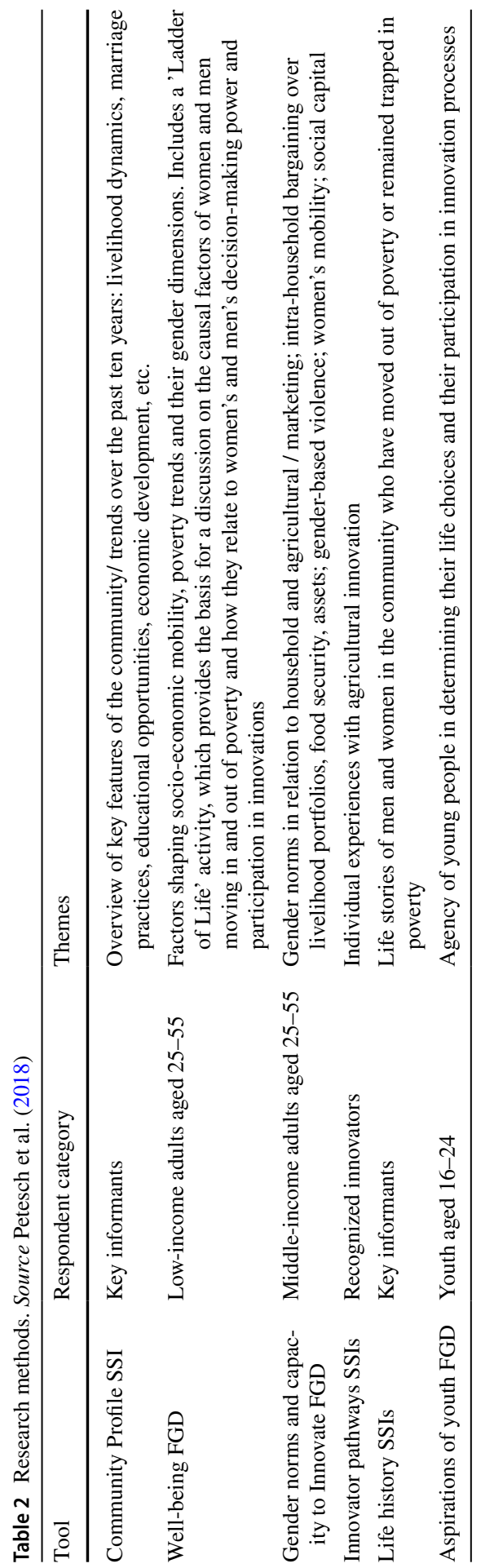

称 
Table 3 Overview of respondents

\begin{tabular}{|c|c|c|c|}
\hline Location of study & Income category & Main castes & Religious affiliation \\
\hline \multicolumn{4}{|l|}{ Low gender gap } \\
\hline Prem, Bihar & $\begin{array}{l}\text { Middle-income } \\
\text { Low-income }\end{array}$ & $\begin{array}{l}\text { OBC: Yadav } \\
\text { SC: various }\end{array}$ & $\begin{array}{l}\text { Hindu }(60 \%) \\
\text { Muslim }(40 \%)\end{array}$ \\
\hline \multirow[t]{2}{*}{ Deva, Uttar Pradesh } & Middle-income & $\begin{array}{l}\text { GC: Chandel Thakurs, Brahmins, } \\
\text { Bhumihars } \\
\text { OBC: Yadav }\end{array}$ & \multirow[t]{2}{*}{ Hindu } \\
\hline & Low-income & $\begin{array}{l}\text { SC: various } \\
\text { OBC: Yadav }\end{array}$ & \\
\hline \multirow[t]{2}{*}{ Cheeda, Uttar Pradesh } & Middle-income & $\begin{array}{l}\text { GC: Kurmi, Baniya } \\
\text { OBC: various }\end{array}$ & \multirow[t]{2}{*}{$\begin{array}{l}\text { Hindu } \\
\text { Muslims (1\%) }\end{array}$} \\
\hline & Low-income & $\begin{array}{l}\text { OBC: various } \\
\text { SC: various }\end{array}$ & \\
\hline \multicolumn{4}{|l|}{ High gender gap } \\
\hline \multirow[t]{2}{*}{ Ganga, Bihar } & Middle-income & $\begin{array}{l}\text { GC: Bhumihar } \\
\text { OBC: Yadav }\end{array}$ & \\
\hline & Low-income & $\mathrm{OBC}$ & \\
\hline Bete, Punjab & $\begin{array}{l}\text { Middle-income } \\
\text { Low-income }\end{array}$ & $\begin{array}{l}\text { GC: Jat } \\
\text { SC: various }\end{array}$ & Hindus, Sikhs \\
\hline \multirow[t]{2}{*}{ Thali, Haryana } & Middle-income & $\begin{array}{l}\text { GC: Rohr, Brahmin Pandit } \\
\text { OBC: Kurmi, Badhi, Kumhaar }\end{array}$ & \multirow[t]{2}{*}{ Hindus, Sikhs } \\
\hline & Low-income & $\begin{array}{l}\text { OBC as above } \\
\text { SC: various }\end{array}$ & \\
\hline
\end{tabular}

SC formed the bulk of respondents in the low-income FGDs. Members of Other Backward Castes (OBC) were distributed between low-income and middle-income FGDs. GC respondents joined middle-income FGDs in all cases. In a few cases, Muslims and Sikhs joined the FGDs, but in low numbers. The majority of respondents were Hindu. The data were gathered in standardized formats, cleaned, and systematically coded using NVivo social science software.

\section{Research Locations}

Prem in Bihar, and Deva and Cheeda in Uttar Pradesh were classified as having low gender gaps. Ganga in Bihar, Bete in Punjab, and Thali in Haryana were classified as having high gender gaps. All low gender gap and high economic dynamism sites experience strong male participation-regardless of caste-in off-farm employment, and short to long-term male outmigration. Conversely, in high gender gap and high economic dynamism sites men, particularly in the middle-income (GC, some OBC) brackets, are primarily farmers and male outmigration, regardless of caste, is low. We now introduce each site in more detail. 


\section{Low Gender Gaps and High Economic Dynamism}

Prem has a population of 2400. Hindus form $60 \%$ and Muslims 40\%. The OBC Yadav caste, $25 \%$, is the most prosperous. SC constitute $26 \%$ of the population. Tobacco, maize, and potato are grown on the uplands and wheat, paddy, and mustard on the lowland. There are pre- to middle schools but no high school. Uniquely in the data set, men set up home independently from their parents upon marriage, meaning that almost all households are nuclear. Around $80 \%$ of men are engaged in local and migrant off-farm work.

Deva has 1700 residents. It is dominated by upper caste Chandel Thakurs, Brahmins, and Bhumihars (66\%). Yadavs (OBC) form 20\%, and SC 13\%. Every household derives part, or all, of their livelihood from farming, growing wheat, paddy, maize, sugarcane, and vegetables. The average landholding is one acre, though $10 \%$ hold more than 12 acres; $85 \%$ of holdings are irrigated. Many men work in local and migrant off-farm occupations.

Cheeda has 2500 residents. Dominant GC castes include Kurmi (30\%) and Baniya $(30 \%)$ and the remainder are SC (22\%), OBC (19\%), and Muslims (1\%). Around $75 \%$ of households depend directly on agriculture. The remainder work as hired labour, run a business, or have salaried employment. Local markets are strong. Considerable development in infrastructure, irrigation, and educational facilities has taken place over the past decade. The average land holding is 0.75 acre, the smallest 0.25 and largest 10 acres. Large farmers represent $1 \%$ of the population. Male outmigration is around $50 \%$.

\section{High Gender Gaps and High Economic Dynamism}

Ganga has a population of 2000. It is dominated by Yadavs (OBCs) and Bhumihars (GC) (relative percentages not captured). OBC are also found in the low-income category. No SC are present. Wheat, paddy, and vegetables are grown, and farming is rainfed. The government has invested heavily in road infrastructure and schooling up to lower secondary.

Bete is home to around 2800. The GC are Jat (41\%) whilst 59\% are SC. Bete has received considerable infrastructure development with most people benefiting from electrification and piped water as well as new roads, health, and educational facilities, a bus line and banks. More than half depend on agriculture with wheat and paddy being the most important crops.

Thali has a population of 3500 . It is home to two religious groups, Hindus and Sikhs, and many castes including Rohr, Brahmin Pandit (GC), Kurmi, Badhi, Kumhaar (OBC), Valmiki, and other SCs comprise $29 \%$ of the population. Whilst a few CG farmers manage 10 acres, small and marginal farmers predominate and $30 \%$ of residents, all of whom are SC, are landless. Almost every farmer has a tube well enabling irrigation. Roads are good and most farmers carry produce to market on tractors. 


\section{Findings}

The findings are presented in two subsections: low and high gender gap communities. In each case, the findings are subdivided by income: middle-income and lowincome. Data on young women, and with respect to local institutional actors, is also presented in each subsection.

\section{Women as Wheat Farmers and Innovators in Low Gender Gap Communities}

\section{Middle-Income Women}

Across the three low gender gap communities, middle-income (OBC and GC) women are increasingly recognized as wheat farmers. This is very different to the scenario painted by Rao (2012) in the introduction where despite women's obvious participation in wheat, neither men nor women acknowledged this. Women respondents in low gender gap communities in this study frequently remarked that "there is not much difference in the way a man works and the way a woman works". Men commented, "women should be allowed to go out and work because this will increase our income and benefit the family".

Widespread male acceptance of women working in the fields is accompanied by recognition of women as decision-makers. In Cheeda, men explained that "50\% of the women in our village do farming themselves or hire labour to do it. They save on both time and labour costs". Furthermore, some women are explicitly being recognized by their spouses as innovators. In Prem, middle-income men explained that "women take risks depending upon how much land and money they have", that "women innovators have the same characteristics as male innovators", and that "women are farmers here and use machines for cultivation". Women select improved wheat varieties and inputs such as inorganic fertilizers. Increasingly, though social norms still prescribe that men should 'not allow their women to use machines', in reality some women use them directly or employ drivers. In Deva, according to community key informants $80 \%$ of farming households use zero tillage. Women remarked, "Women can easily employ labour on their land and get the work done by zero till planters whilst their husbands are away". Since the owners of machinery have a vested interest in renting machinery to women, they teach women how to use them and thus women's technical knowledge is improving.

In Cheeda, a women wheat innovator, Meena, explained how she now takes joint decisions with her migrant husband. Immediately after he left, she had to do most of the work on the farm. This was time-consuming and "we were always under pressure. Our production volumes were low and despite putting our best efforts into the crop we did not manage to get enough for our own consumption. When the village head tried to convince us that by using the zero tiller we would increase our yield we were excited to try it out". Now, she says, "we should be machine-friendly since they are made for our benefit. They have enabled me to spend more time at home with my family and I also get time to put up my feet for rest". 
Further evidence for an increase in middle-income women's managerial capacity is provided by data on changes in women's decision-making over the past ten years. In all three communities, participants claimed their decision-making capacity had doubled, or more, over the past decade, and that their sense of self-worth and dignity has increased. Whilst some of this is undoubtedly life-cycle related, women were anxious to discuss other factors. For instance, in Prem, many women stated that since men were never around to take decisions women had to take responsibility. "What decisions can men take when they are not home? They all live elsewhere earning money". Another woman added, "Earlier men made all decisions but today women go out for everything. We are called for meetings and to children's schools. We buy groceries and everything". In Deva, study participants' felt levels of decision-making capacity were lower though still fairly strong. One woman commented, "we don't have full rights to take all decisions but we can take a few".

In Cheeda, middle-income women argued their decision-making power has increased greatly. They asserted they do not take 'final' decisions, but that they 'confidently' advise their husbands. "If we hear of something new we advise our husbands", and "we tell them that we have heard of this new wheat seed variety and that they should buy it", and "if we hear of a new fertilizer we tell our husbands". Perhaps as a consequence of the subtlety of advice, some men remaining in the community felt that women "are not innovators" and that "women always follow men". When men are absent, however, women exert decision-making more openly. A recognized wheat innovator explained that "now my husband works away. For all practical purposes I take decisions for my family but I always consult him on phone first". Women explained that wives must take decisions in their husband's absence: "women enjoy decision-making rights which previously belonged only to their husbands".

Overall, middle-income women in low gender gap communities attributed their improved decision-making power directly to male outmigration and to education. Whereas women's decision-making in the absence of men was seen as a practical necessity (which also brought economic benefits to the family), education brought more intangible and synergetic gains. One older woman explained. "We started going to school, we gained more experience, our thinking widened and we became wiser".

\section{Young Women}

This increase in women's agency is inter-generational. In all three low gender gap communities, young women feel strongly empowered and experience good mobility (including young married women). "Today girls go to school and learn so many new things that it gives us the courage and confidence to speak up." Young women in Cheeda were very clear. "When our parents decided to send us to school, they decided to empower us". Education taught them to "speak up for ourselves and we $d o$ ", and so "our parents listen to us". One young woman summed up the situation: "education has brought about a revolutionary change. We are wiser and more capable". Intriguing feedback loops between younger and older women have emerged. 
One mother said, "Now my children tell me what is right and wrong and they say that I should also have an opinion".

\section{Low-Income Women}

There is no evidence of SC women in low or high gender gap communities retiring to the household should their economic situation improve. This is not part of their caste identity (Rao 2012). This allows SC women to innovate should a favourable constellation of circumstances facilitate expression of their agency. In Prem, for example, an illiterate and previously poor SC woman, Ananya, is now recognized in her own and surrounding communities as a successful and wealthy wheat innovator. She began when her husband out-migrated after ceding control over the land to her. Together with her children, she worked hard and began to visit the local demonstration farm. One low-income man, commenting on her success, said that it is now clear that women can do everything from growing their own crop to selling it at the marketplace. In Ananya's case, the dedicated support of wheat researchers at a nearby research station was important to her success.

Women in the very few low-income households in low gender gap communities which manage to hire agricultural machinery praised these technologies. They considered that men, and the household, benefit. "Earlier all male members had to work together to get our land ready for sowing. Not anymore. Now only one family member goes to supervise the work done by the rotovator driver". Poor men are freed to work on various off-farm activities, with brick kilns being an important source of employment in several locations. Poor women also appreciate being released from arduous agricultural work. In cases (such as the economically dynamic communities we studied) where reasonable income generation alternatives to hired labour in farming exist, poor families with land who can hire machinery seem able to benefit.

\section{Locally Important Institutions}

In low gender gap communities, middle-income women's engagement with the RAS and research organizations was weak although there were some links as noted above for individual women. In Prem, a few women engage with extension agents, and a research organization provided individualized support to some women innovators. Women and men in Cheeda and Deva agree that women do not learn directly from extension agents and research organizations but depend on their families and friends for help and information because-according to men "women cannot go hunting experts for help".

Village heads are decisive for determining the levels of middle-income (GC and OBC) women's inclusion or exclusion from village level meetings. In each of the three communities, the village head has mechanized his agricultural operations and typically rents out his machinery. He often owns the only zero till planter in the community. The village head in Cheeda has formalized women's inclusion by inviting them to weekly meetings called baithaks. These are conducted at his residence and allow farmers to share information and have their queries answered. In Prem, 
women feel they are given pride of place at community meetings. In particular being given chairs raises their self-esteem. The fact that renting machinery to women is financially beneficial to the village head or large farmer significantly contributes to the willingness of these men to include women.

Large farmers can be an important source of information for low-income farmers. "Poor farmers go to bigger farmers for help and information" according to women. In all low gender gap communities, where women's mobility is relatively high, shopkeepers selling inputs emerged as a critical source of information for low- and middle-income women (as well as men).

\section{Women as Wheat Farmers and Innovators in High Gender Gap Communities}

\section{Middle-Income Women}

In high gender gap communities, the situation for women is very different. Whereas the combination of economic dynamism and mechanization in low gender gap communities is increasingly allowing women to participate actively as decision-makers in wheat farming, the same combination in high gender gap communities is pushing middle-income OBC and GC women farmers who previously provided their labour for wheat production back into the household. The difference between the two types of community is that male outmigration in the high gender gap communities is very limited. As a consequence, men are present in the community and in the home and are strongly identified as 'the' farmers. Social norms which for generations have frowned upon $\mathrm{OBC}$ and GC women working in the field are now being implemented, resulting in women leaving fieldwork. The whole process appears to be reinforcing male control over wheat as well as women, particularly in the GC and OBC caste categories.

Across all three high gender gap communities $\mathrm{GC}$ and $\mathrm{OBC}$ men agreed that "women cannot be innovators". One commented, "women don't have any brains and so they can't make suggestions". Men everywhere saw themselves as breadwinners with the capacity to learn about innovations and also the necessity of doing so. They did not see any complementarities between women and men's roles in agriculture. Men asked, "Why should a woman bother about these things when her husband is there to decide on such matters?" They argued that "women's domain is their home", and "only when men are not around do their wives go to work in the fields". Men expressed pride in providing for their families and want their wives to remain at home cooking, cleaning, fetching firework, and taking care of children and elderly family members. "We are there to take care of the needs of our homes and our women need not step into our shoes."

In sharp contrast, women expressed frustration with their exclusion. In Bete, a woman highlighted the power of norms governing intra-household decision-making and gender roles. "A man would rather die than let his wife step into the male domain". In Thali, women explained. "Men know all about innovations. Women are 
not allowed to learn." Another said, "Even if the women want to learn and to work, their husbands do not allow them", and another woman added, "my husband would kill me if I said I want to work". There are some changes, though. Some middleincome women in Thali assert an increase in empowerment over the past decade because now they can contribute to discussions in general, though independent decision-making is mainly restricted to decisions about what to cook and clothes for children. "Now women are more aware and consider themselves more capable", whereas "ten years ago we did not even go in front of the elders in our family" and "I don't remember if I took any decisions. Now at least I speak my mind".

In Ganga, women explained they do not take any decision around agricultural innovation, but nevertheless, they quietly support husbands, sometimes by giving suggestions, or through selling their personal items such as jewellery to enable rental or purchase of machinery. More broadly, some women who no longer work in the fields and experience seclusion, felt that due to education, postponement of marriage, and their increasing participation in home-based businesses, they were becoming more equal to men.

Women from successful wheat innovator families outlined benefits to mechanization: their husbands now have enough time to take up other paid work opportunities thus increasing household income, and as fathers they spend more time with the family. A few women have started working from home as tailors and beauticians and others feel relaxed because "now we can complete our household chores at a more relaxed pace".

\section{Young Women}

A young woman summed up life rather bleakly. "We study, stay home, get married". In common with low gender gap communities, adult girls are supporting their mothers to speak more freely. Women in Bete, a high gender gap community, explained, "Our daughters have grown up and they tell us that we must speak up for ourselves and participate in all decision-making processes". Even so, the data from young women suggests they experience low agency over their lives.

\section{Low-Income Women}

Some low-income households in all three high gender gap communities participate in agricultural innovation processes. Motivated by observing the successful use of technology by richer farmers some poor households are taking out leases on land and renting machinery, and purchasing improved wheat seeds. When they succeed, poor women feel "able to relax". In Bete, Saanvi, a widow, decided to innovate despite her lack of formal education. Saanvi initially drove the tractor just like her husband had done to prepare her field. She then shifted to the zero till planter. She explains that her innovative practice was fully supported by a local farmers' organization. Today, she only needs to supervise work on her farm and "is not hard pressed for time any more. I can pack in all my day's work easily now and still find time to sit and chat with my children". Kyra, a married woman with a migrant 
husband, likewise from Bete, explains, "I am a woman managing 5.5 acres of land on behalf of my father, and growing my own crop. I use machines. I am not afraid of machines". Kyra stressed that "there should be training sessions where women can be educated about the benefits of machinery". Finally, in Ganga, a woman innovator was strongly supported by the young, educated village head. Talking about the changes, this has brought to her life she indicated that her family were now eating and living well and, "I take all the important decisions in my family and command more respect now. The big change is that earlier I was a labourer whereas now I am a farmer".

Life has changed for these previously poor women who, either alone or together with husbands, have been able to invest in innovations. They now participate much more actively in intra-household decisions, particularly as they became wealthier and move above the locally assessed poverty line. It is important to highlight that these women were outliers in our study. However, their experiences and trajectories show the potential of poor women from marginalized castes to succeed. The key ingredients were the will of the women themselves to succeed coupled with institutional support-from wheat researchers, agricultural organizations, and village heads. This support is highly individualized and does not represent any form of structural transformation at present.

The findings are clear that the majority of poor households continue with hand tools, and poor women in high gender gap contexts generally face the same desperate situation as their peers in low gender gap communities. They have lost work as labourers to a greater extent than men, and find it harder to get work. Some alternative income generation opportunities for poor women exist in factories, brickmaking and through the Mahatma Gandhi National Rural Employment Guarantee Programme.

\section{Locally Important Institutions}

In high gender gap communities, women, regardless of caste status, are usually excluded by the RAS: "Extension agents never approach us". A woman said simply. "We cannot innovate or adopt an innovation if we are not aware of it". Women explained that even if they were to be invited to meetings, they would have to stay under veils and remain silent, which would not help them in getting their queries addressed. A middle-income man explained, "Women are the pride of our families and they cannot go hobnobbing with others".

Only in Bete, a high gender gap community, SC generally were becoming wealthier. This was also the only community where farmers were leasing land rather than sharecropping. This facilitated wealth accumulation. All farmers have a tube well and all grow wheat. SC alongside GC farmers were improving agricultural productivity, and many SC, including women, were obtaining higher wages by working offfarm in a local factory. The Bete Agricultural Cooperative (BAC) was pivotal in this transformative effect. No farmers-regardless of income level-purchased machinery because the BAC rented machinery to them at a fixed, reasonable rate. Poorer farmers come together to pay rental fees. BAC also provides extension services and 
credit. Women, who due to caste dictates, rarely work in the field but have some decision-making capacity, claimed they could obtain credit on fair terms from BAC. BAC conducts regular meetings to which all farmers, regardless of caste or gender, are invited. The village head additionally helps everyone, regardless of caste or income status, with agricultural advice.

Similarly to low gender gap communities, low-income farmers find large farmers to be a useful source of advice.

\section{Discussion}

Two hypotheses guided the analysis of research findings. First, we hypothesized that due to strong cultural norms which construct men as farmers and which privilege male agency, the transitioning of women from labourers in wheat to innovators and managers of wheat is likely to be far from straightforward. Second, we hypothesized that women are actively managing the processes unleashed by various sources of change. We used the concept of doxa to help us focus our analytic lens upon the strategies women use to assume some degree of control.

We now present Fig. 2. 'A typology of women's strategies to strengthen their managerial decision-making power in wheat' to pull out and systematize the findings. We find that there is a graduated typology of six strategies. The right-hand side of the figure sets out the typology of women's strategies to participate in decisionmaking in relation to wheat. (It is important to note that our data do not allow us to categorically associate specific castes to a particular strategy. However, caste status or any other marker, such as ethnicity, age, sexuality, and so on, could be added to the typology through adding a new column to the right.) The left-hand side locates external agencies in relation to their support of, or otherwise, each strategy. Returning to Conceptual Framework, we argued that institutional actors are among those which patrol the doxic boundary and mobilize social norms to either support or discourage challenge to doxa.

Figure 2 places the six strategies we have identified within three broad domains (A, B, and C) which represent different relationships to doxa. As a reminder Bourdieu (1977) argues that doxa represents unspoken tradition. Because it is unspoken, 'it is the most powerful rule of all' (ibid.). Domain A thus presents the doxa that men are sole decision-makers in relation to wheat. However, since our findings suggest that this doxa is being challenged, the lightening of the colour shows how it is weakening as women develop increasing assertive strategies. Domain B indicates a growing awareness by women that this doxa exists. Doxa is becoming part of opinion but not yet open discourse or challenge. The top domain, Domain $\mathrm{C}$, is the domain of open discourse and challenge. For analytic clarity, women's strategies are discussed separately here, though in reality they are more messy. 


\section{Relationship of External Typology of Women's Strategies Institutions to Doxa towards Doxa in Wheat}

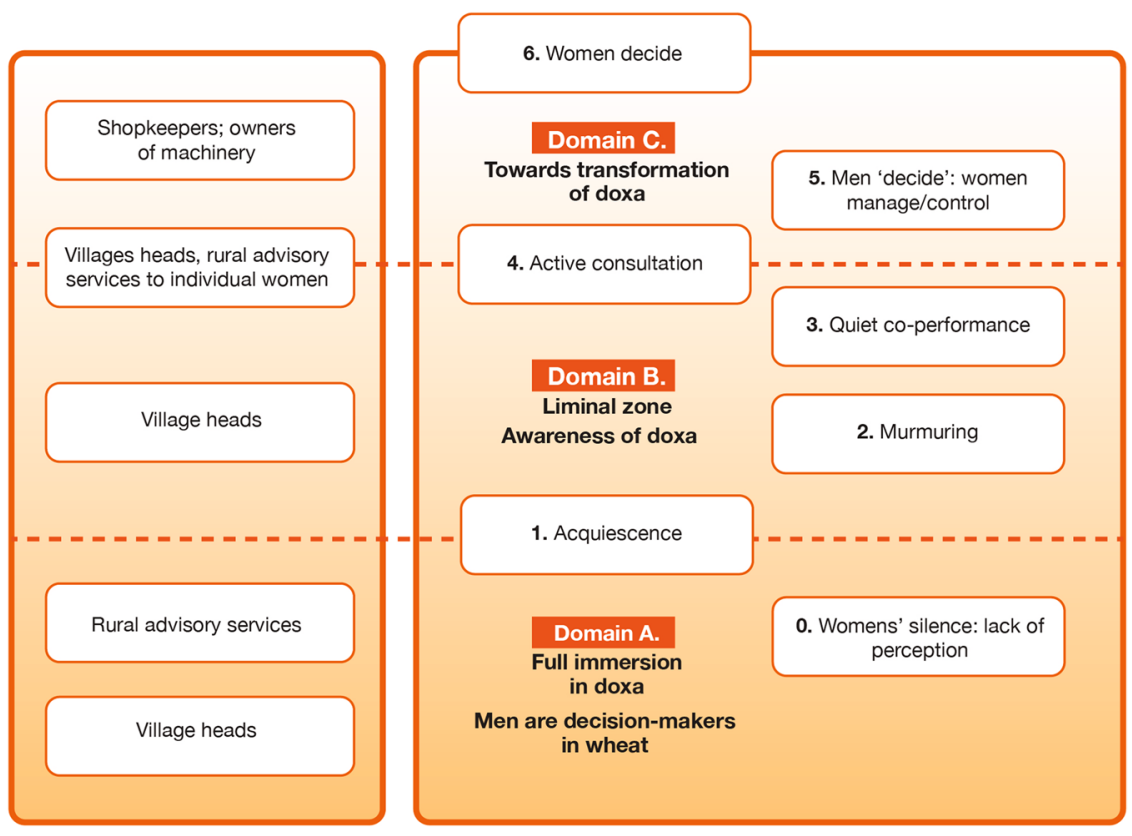

Fig. 2 A typology of women's strategies to strengthen their managerial decision-making power in wheat

\section{Domain A: Immersion in Doxa}

\section{Strategy 0: Non-awareness}

The doxa that women have no role to play in agricultural decision-making is held by the majority of upper caste men respondents in the high gender gap communities. There is no evidence that women are unaware of this doxa and take it as part of the natural order. Nevertheless, an upper caste woman in a high gender gap community crystallized the reality of this form of doxa by reflecting 'I don't remember if I had an opinion at that time.' Sen (1985) describes the lack of correlations between objective measurements of deprivation and subjective awareness of it. In relation to women's lower access (compared to men) to sufficient food and nutrition, a woman 'may be resigned to her state, or have internalized cultural norms that allot her an impaired status. When she is judged by the metric of desire or happiness fulfilment, therefore, she may seem to be doing quite well although she is physically quite deprived'. Such a lack of self-awareness embodies how doxa harmful to women can operate below conscious awareness. 


\section{Domain B: Liminal Zone: Strategizing Around Doxa}

A liminal zone is a zone of transition.

\section{Strategy 1: Acquiescence}

In high gender gap communities, middle-income upper caste women and men refer to norms which were once subliminal, but which are now emerging into opinion, although these norms are not yet openly discussed and contested. The weakest form of resistance to doxa is women's silence expressed as acquiescence. Risseeuw (2005) calls this the line of separation between the 'most radical forms of misrecognition', and 'the awakening of political consciousness'. Many women met in the study recognized that they were not expected to take part in agricultural decision-making, but did not articulate any forms of resistance.

Reisseuw (ibid.) argues that the potential to operate without formulated conflict must be incorporated into theory. The less powerful must be accorded a sense of awareness of their disadvantaged position. Even if this entails non-articulation or indirect forms of resistance, it should not be equated with ignorance. She adds that the relationship between powerful and less powerful is necessarily dynamic. It is not only women who change. Power relations have a dual effect, forcing those whose basis of power is increasing to transform themselves in relation to the 'other' whom they come to believe they must rule, oppress, protect or guide (ibid.). Middle-income men in the high gender gap communities express all of these beliefs. Injunctive norms imposed by men are clear: "we are there to take care of our homes" and "women need not step into our shoes". Such injunctive norms attempt to squeeze that which 'goes without saying and that which cannot be said' back into doxa. Men demonstrated that they understand the function of injunctive norms to be to quell women's discontent, and if it is too difficult to ignore, to diminish it—-women don't have brains".

\section{Strategy 2: Murmuring}

A stronger form of resistance can be termed 'murmuring', here defined as a rumble of discontent or grumbling. Murmuring is expressed in ironic remarks by middle-income women in high gender gap communities in reflections upon their inability to learn directly about innovations and to participate in decision-making. They are fully aware of the power of injunctive norms: "he will kill me". Ahluwahlia (1997) provides a similar example from Rajasthan, where the workload of women increased by up to three hours a day following the enclosure of the village commons at the instigation of a development agency. Women did not participate in the decision to enclose the commons but bore the costs in terms of more work obtaining water, fodder, and fuel. Although they complained of overwork and fatigue, none openly questioned decisions taken by men. Ahluwahlia concludes, "This is not surprising as the institutions which subordinate women, and 
repress their desires, speech, ideas and even emotions, remain very strong" (ibid.: 33).

\section{Strategy 3: Quiet Co-performance}

A step change occurs with middle-income women, particularly $\mathrm{OBC}$ in high gender gap communities, beginning to support men's ability to innovate, for example through buying machinery, financially through selling jewellery, obtaining credit, and so on (as well as through carefully nuanced 'suggestions' or 'advice'). The 'right' of men to be sole decision-maker in wheat is not questioned; rather the evidence suggests that women are openly, but 'quietly' supporting men in ways which do not challenge social norms. Rather than interpret this as a form of subjugation, it appears that such women are actively deploying male agency to support their individual and household-level goals. Middle-income women, enabled through mechanization to retire from the field, see an opportunity to increase their own well-being, expressed as having time to spend on themselves and their children, as well as on developing their own businesses. Mechanization also frees men to engage in offfarm work, thus increasing overall household income.

Rao (2012) suggests that women and men 'co-perform' to jointly construct women as 'housewives' (even if they actually work outside the home) and men as 'providers'. Given the impossibility of challenging the entire context within which they live, Rao argues, women deploy their agency by seeking reciprocity for their contributions from their spouses. Women 'by quietly serving their men' improve their own individual position. She concludes, though, that when women's agency is expressed like this it is incremental and individualistic. It does not change the meaning of gender in long-lasting or transformative ways (ibid.).

\section{Domain C: Towards Transformation of Doxa}

The strategies described in Domains A and Bare deployed primarily by middleincome $\mathrm{GC}$ and $\mathrm{OBC}$ women in high gender gap communities. OBC women in low gender gap communities dominate the strategies identified in Domain C. SC women use all three strategies below, but due to their overall low participation in wheat innovation processes our data and thus understanding of their strategies is weaker. Nevertheless, it appears that due to their caste identity, which permits mobility and work in the fields, SC women seem to adopt Strategy 6 more than OBC.

\section{Strategy 4: Active Consultation}

Women are recognized as wheat farmers. Men overtly recognize, and state, that women are-alongside men-wheat farmers: "there is not much difference in the way a man works and the way a woman works". This is also an expression of male agency, because redefining 'who does what' frees men to engage in off-farm work. Men remain key decision-makers in wheat but women seek, and obtain, consultation rights in their role as farmers. 


\section{Strategy 5: Men ‘Decide': Women Manage/Control}

In all three low gender gap communities, women farmers in all income categories are increasingly 'consulting' men with regard to innovation practices whilst simultaneously managing the flow of information. It is here that women's skills in promoting their gender interests-whilst maintaining the doxa that men are ultimate decision-makers - are particularly evident. Most women stressed that they phone their husbands regarding decisions to be taken regarding innovations. He is expected to take the final decision. However, women equally made it clear that 'consultation' involves presenting absent men with specific options to consider, such as a new variety of wheat seed. Women are therefore pre-determining the range of decisions their spouses can make. In this sense, consultation appears formulaic. The doxa norm that men take decisions is openly respected, but sometimes appears to be almost entirely hollowed out. Women steer discussion to the outcomes they require in order to farm and innovate as they choose.

\section{Strategy 6: Women Decide}

Finally, in low gender gap communities, some women—particularly SC-take all decisions in relation to farming and innovation. Whilst few, such women are not punished through the imposition of negative injunctive norms. It is possible that such women have not yet reached a critical mass and so can be respected, even admired. These women may be offering migrant men the security of knowing their wives can manage to run the farm in their absence, thus reducing livelihood uncertainties. Furthermore, work in agriculture is part of the caste identity of SC women, and thus, overt decision-making may seem less transgressive.

\section{Local Institutions Often Remain Harmfully Locked in Doxa}

The evidence presented here shows that women, regardless of caste identity and socio-economic class, have developed a range of strategies to insert themselves into innovation processes and seek inclusion. However, the study finds that the RAS-as a category of institutional actor (including government, research and private sector actors) - make few efforts to include women, regardless of income band or caste status, in training events and information dissemination. All RAS in our study sites completely ignore $\mathrm{SC}$ with marginal lands.

This said, we recognize that individual extension officers sometimes devote considerable time to helping women and SC more broadly. Research organizations and village heads may mobilize such support from the RAS as well, in order to assist women innovators. However, there is no evidence of institutional support from the RAS despite women's self-evident work in the fields, interest in machinery and innovation processes more broadly, and despite the high rate of male outmigration in some locations, which makes supporting women in wheat a necessity. Through their activities, RAS enact a form of orthodoxy by continually patrolling and maintaining the boundaries of an outdated doxa that is increasingly recognized by farmers 
themselves as no longer fit for purpose, although not always openly articulated as such. By way of contrast, progressive village heads and farmer cooperatives like the BAC mentioned above can be decisive in facilitating the participation of middleincome women in wheat innovations. In all cases, though, institutional support like this is ad hoc. Furthermore, village heads almost never interact with SC and other low-income farmers in relation to wheat. This is despite evidence that poor women and men are fighting to participate, by raising money for investment in new technologies, observing innovative farmers, and so on. Inclusion is particularly important for poor women because it is considerably harder for them than their husbands, to out-migrate or exploit other livelihood options. These people really are 'clinging on'.

\section{Conclusion}

It is not clear where processes transforming doxa in low gender gap communities will end. It is possible that the strategy of women consulting men may represent a satisfactory solution, whereby a hollowed out doxa of men as agricultural decisionmakers is acknowledged, but women are enabled to act effectively as decision-makers in all but name. If this occurs, it will presumably be supported by the emergence of new descriptive norms acceptable across (large sections of) whole communities, which recognize women as wheat farmers. In such case, injunctive norms would develop which reward women as innovators and managers (as they are beginning to do in outlier cases of recognized women innovators) and potentially even penalize men who insist upon retaining close control even in their absence. If this situation were to come about, women's capacity to act and participate in innovation processes would be formalized as normative.

Strategies 1-4 seem to conform to Kandiyoti's (1988) analysis that women's strategies play out in the context of patriarchal bargains. These are implicit scripts, which define, limit, and inflect women's options (ibid., p. 285). However, we have identified evidence that new strategies (5 and 6) are emerging whereby women are actively transforming the content of patriarchy. We consider that the concept of patriarchal bargains does not cater for men's, as much as women's, willingness to consider partial or complete transformation of the patriarchal bargain in relation to wheat. In low gender gap communities experiencing high outmigration, men benefit from their freedom from doxa that expect them to be primary farmers, agricultural decision-makers, and breadwinners. They are coming to realize, and openly acknowledge, that asserting male primacy in agricultural decision-making does not make sense when they are not physically present.

The findings indicate that education is an important transformative force upon doxa, though male outmigration has further facilitated this transformation by creating spaces wherein women must act if farming is to survive as a viable livelihood option. Women in both high and low gender gap communities agree that education allows them to think differently about themselves and their capacities. Nussbaum (2001, pp. 62-63) considers women may feel 'conditioned satisfaction' with their (harsh) lives. However, she argues, such women may have only 
been able to pursue one kind of life. Had they been offered an education, say, a whole array of different options may have enabled them to live quite differently. The findings indeed show that women across all communities are perceiving different kinds of lives and taking steps to realize these options. However, the relative strength of doxa continues to shape the range of options a woman may pursue in her specific context. That is to say, there is a mismatch between what she may perceive as 'the widest sense of limits' (ibid.) of what she could do, and what she knows she will actually be able to achieve. This mismatch is particularly clear in the high gender gap communities.

It is clear that addressing the reality of women wheat farmers as managers, leaders, and innovators in wheat farming is a significant challenge for RAS and some village heads in low and particularly high gender communities. Some of these institutions, through strict observance of an outdated perception of doxa in their daily practice, constitute a powerful brake upon what women and men are able 'to imagine, to wonder and ... to know' (Nussbaum and Sen 1993, pp. 1-2). Institutional marginalization of women, and of scheduled castes, poses a serious constraint on the attempts of women and men wheat farmers to realize their aspirations and livelihoods.

Exploring partnerships with private sector players is potentially one way out of this impasse. Our evidence is limited, but what we do have indicate that input sellers at least are already recognizing and profiting from women's increased decision-making power in low gender gap communities. Supporting village heads to redefine doxa at community level is important because this helps provide a seal of legitimacy. Working with women's organizations and networks is critical, because empowerment is a process of discovery by its participants and cannot be imposed. Agricultural research and development actors must engage seriously with the reality of women in wheat in high and low gender gap communities. Part of this will entail recognizing the ways in which they have hitherto unquestioningly supported the doxa of men as decision-makers in wheat. Moving forward entails developing, with women and men, norms which acknowledge women as workers and decision-makers in wheat.

We conclude by returning to our words in the Introduction. It is our hope that researchers trying to understand empowerment dynamics and how to think about women's agency will find our typology useful and experiment further with it. Other development partners, on the basis of our framework, should be able to more readily perceive that women develop a range of strategies that they carefully nuance, and which they own. Such strategies can be sensitively supported but they must be left in the hands of the women themselves to manage.

Acknowledgements This paper draws on data from GENNOVATE case studies developed in India under the CGIAR Research Programme on Wheat-which also funded data collection. Development of the research methodology was supported by the CGIAR Gender and Agricultural Research Network, the World Bank, and the CGIAR research programmes on Wheat and Maize. Data analysis was supported by the Bill and Melinda Gates Foundation and the CGIAR Research Programme on WHEAT. The authors thank Anuprita Shukla, the women and men farmers who participated in this research, and the data collection team including Ajay Dubey, Prabin Prasad, Bharti Sakhya, and Surabhi Tiwari. The views expressed in the article are those of the authors and not of any organization. 
Open Access This article is licensed under a Creative Commons Attribution 4.0 International License, which permits use, sharing, adaptation, distribution and reproduction in any medium or format, as long as you give appropriate credit to the original author(s) and the source, provide a link to the Creative Commons licence, and indicate if changes were made. The images or other third party material in this article are included in the article's Creative Commons licence, unless indicated otherwise in a credit line to the material. If material is not included in the article's Creative Commons licence and your intended use is not permitted by statutory regulation or exceeds the permitted use, you will need to obtain permission directly from the copyright holder. To view a copy of this licence, visit http://creativecommons.org/licen ses/by/4.0/.

\section{References}

Agarwal, B. 1997. "Bargaining" and gender relations: within and beyond the household. FCND discussion paper 27. Washington, DC: IFPRI.

Aryal, J.P., C.R. Farnworth, R. Khurana, S. Ray, and T.B. Sapkota. 2014. Gender dimensions of climate change adaptation through climate smart agricultural practices in India. New Delhi: Innovation in Indian Agriculture: Ways Forward, Institute of Economic Growth (IEG).

Aryal, J.P., D.B. Rahut, M.L. Jat, S. Maharjan, and O. Erenstein. 2018. Factors determining the adoption of laser land leveling in the irrigated rice-wheat system in Haryana, India. Journal of Crop Improvement 32 (4): 477-492. https://doi.org/10.1080/15427528.2018.1457584.

Badstue, L., P. Petesch, G. Williams, A. Umantseva, and D. Moctezuma. 2017. Gender and innovation processes in wheat-based systems. GENNOVATE report to the CGIAR research program on wheat. GENNOVATE research paper. Mexico, DF: CIMMYT.

Ball Cooper, L., and E. Fletcher. 2012. Reducing societal discrimination against adolescent girls using social norms to promote behavior change. London: Girl Hub.

Bourdieu, P. 1977. Outline of a theory of practice. Cambridge studies in social and cultural anthropology, vol. 16. Cambridge: Cambridge University Press.

Chauhan, B.S., G. Mahajany, V. Sardanay, J. Timsina, and M.L. Jat. 2012. Productivity and sustainability of the rice-wheat cropping system in the Indo-Gangetic plains of the Indian subcontinent: problems, opportunities, and strategies. Advances in Agronomy 117: 315-369.

Chayal, K., and B.L. Dhaka. 2010. Analysis of role performance of women in farm activities. Indian Research Journal of Extension Education. 10 (2): 109-112.

Cislaghi, B. and Heise, L. 2017. Measuring gender-related social norms: Report of a meeting, Baltimore Maryland, Learning Group on Social Norms and Gender-based Violence of the London School of Hygiene \& Tropical Medicine, 14-15 June 2016, https://strive.lshtm.ac.uk/resources/norms-measu rement-meeting-learning-report.

Cohen, P., S. Lawless, M. Dyer, M. Morgan, E. Saeni, H. Teioli, and P. Kantor. 2016. Understanding adaptive capacity and capacity to innovate in social-ecological systems; applying a gender lens. Ambio 45 (3): 309-321.

Cornwall, A. 2016. Women's empowerment: What works? Journal of International Development 28: 342-359.

Da Corta, L., and D. Venkateshwarlu. 1999. Unfree relations and the feminisation of agricultural labour in Andhra Pradesh. In Rural labour relations in India, ed. T.J. Byres, K. Kapadia, and J. Lerche, 71-139. London: Frank Cass.

De Neve, G. 2017. The sociology of labour in India. Contributions to Indian Sociology 33: 1-2.

Drucza, K., and V. Peveris. 2018. Literature on gendered agriculture in Pakistan: Neglect of women's contributions. Women's Studies International Forum 69: 180-189. https://doi.org/10.1016/j. wsif.2018.02.007.

Farnworth, C.R. 2007. Achieving respondent-led research in Madagascar. Gender \& Development 15 (2): 271-285.

Farnworth, C.R., and K.E. Colverson. 2015. Building a Gender-Transformative Extension and Advisory Facilitation System in Sub-Saharan Africa. Journal of Gender, Agriculture and Food Security 1 (1): 31-50. 
Farnworth, C.R., T. Jafry, K. Lama, S. Nepali, and L. Badstue. 2018. From working in the wheat field to managing wheat. Women innovators in Nepal. The European Journal of Development Research 31 (2): 293-313.

Garikipati, S. 2008. Agricultural wage work, seasonal migration and the widening gender gap: evidence from a semi-arid region of Andhra Pradesh. European Journal of Development Research 20 (4): $629-648$.

Gartaula, H., A. Niehof, and L. Visser. 2012. Shifting perceptions of food security and land in the context of labour out-migration in rural Nepal. Food Security 2012 (4): 181-194. https://doi.org/10.1007/ s12571-012-0190-3.

Ghosh, M., and A. Ghosh. 2014. Analysis of women participation in Indian Agriculture. International Journal of Gender and Women's Studies 2 (2): 271-281.

Goudappa, S.B., S. Surekha, and B.S. Reddy. 2012. Participation of farm women in decision-making process on agricultural operations in Yadgir District of Karnataka. Indian Research Journal of Extension Education 1: 138-143.

Guérin, I. 2013. Bonded labour, agrarian changes and capitalism: emerging patterns in South India. Journal of Agrarian Change 13 (3): 405-423.

Gulati, K. 2016. Who's the Boss? In Intra-household valuation, preference heterogeneity, and demand for an agricultural technology in India. https://economics.ucr.edu/pacdev/pacdev-papers/who_is_the_ boss_intrahousehold.pdf.

Jafry, T. 2013. Integration of gender and social equity in R4D on wheat-based systems in South Asia. Scoping study report to the GGIAR research program on wheat. Mexico, DF: CIMMYT.

Jafry, T. 2016. Making the case for gender sensitive climate policy-Lessons from South Asia/IGP. International Journal of Climate Change Strategies and Management 8 (4): 559-577. https://doi. org/10.1108/IJCCSM-04-2015-0049.

Jat, R.K., T.B. Sapkota, R.G. Singh, M.L. Jat, M. Kumar, and R.K. Gupta. 2014. Seven years of conservation agriculture in a rice-wheat rotation of Eastern Gangetic Plains of South Asia: yield trends and economic profitability. Field Crops Research 164: 199-210.

Kabeer, N. 1999. Resources, agency, achievements: Reflections on the measurement of women's empowerment. Development and Change 30: 435-464.

Kandiyoti, D. 1988. Bargaining with patriarchy. Gender and Society 2 (3): 274-290.

Landesa and Oxfam. 2013. A Land of My Own: Facts About Property Rights of Women in India. New Delhi: Oxfam.

Nussbaum, M. 2001. Women and human development. Cambridge: Cambridge University Press.

Nussbaum, M., and A. Sen. 1993. Introduction. In The quality of life, ed. M. Nussbaum and A. Sen. Oxford: Clarendon Press.

Pattnaik, I., K. Lahiri-Dutt, S. Lockie, and B. Pritchard. 2017. The feminization of agriculture or the feminization of agrarian distress? Tracking the trajectory of women in agriculture in India. Journal of the Asia Pacific Economy. https://doi.org/10.1080/13547860.2017.1394569.

Petesch, P., L. Badstue, L. Camfield, S. Feldman, G. Prain, and P. Kantor. 2018. Qualitative, comparative and collaborative research at large scale: The GENNOVATE field methodology. Journal of Gender, Agriculture and Food Security 3: 28-53.

Qadir, A. 2015. When heterodoxy becomes heresy: Using Bourdieu's concept of doxa to describe statesanctioned exclusion in Pakistan. Sociology of Religion. https://doi.org/10.1093/socrel/srv015.

Rao, N. 2011. Gender, land and resource rights in India. In Du grain à moudre. Genre, développement rural et alimentation. Actes des colloques genre et développement, Hg. Christine Verschuur, 209245. Berne: DDC Commission nationale suisse pour l'UNESCO; Genève: IHEID

Rao, N. 2012. Male 'providers' and female 'housewives: A gendered co-performance in rural North India. Development and Change 43 (5): 1025-1048.

Rapley, M. 2003. Quality of life research: A critical introduction. London: Sage.

Risseeuw, C. 2005. Bourdieu, power and resistance: Gender transformation in Sri Lanka. In Sage masters of modern social thought: Pierre Bourdieu, ed. Derek Robbins, 93-112. London/New Delhi: Sage Publications.

Saha, S., R. Goswami, and S.K. Paul. 2018. Recursive male out-migration and the consequences at source: A systematic review with special reference to the left-behind women. Space and Culture, India. https://doi.org/10.20896/saci.v5i3.289.

Sen, A.K. 1985. Commodities and capabilities. Amsterdam: North-Holland.

Shiva, V. 1991. Most farmers in India are women. New Delhi: FAO. 
Sinha, B., S. Jha, and N.S. Negi. 2012. Migration and empowerment: the experience of women in households in India where migration of a husband has occurred. Journal of Gender Studies 21 (1): 61-76.

Stewart, F. 2013. Capabilities and Human Development: Beyond the individual-The critical role of social institutions and social competencies. Occasional paper 2013/03. Geneva: UNDP.

USDA Foreign Agricultural Service. 2017. India grain and feed annual. Gain report number: IN7031. Prepared by Singh, S.K. https://gain.fas.usda.gov/Recent\%20GAIN\%20Publications/Grain\%20and \%20Feed\%20Annual_New\%20Delhi_India_2-23-2017.pdf.

Verma, S.K. 1992. Women in agriculture: A socio-economic analysis. New Delhi: Concept Publishing Company.

Young, H.P. 2015. The evolution of social norms. Annual Review of Economics. 20157 (1): 359-387.

Publisher's Note Springer Nature remains neutral with regard to jurisdictional claims in published maps and institutional affiliations.

\section{Affiliations}

\section{Cathy Rozel Farnworth ${ }^{1}$ (D) $\cdot$ Tahseen Jafry $^{2}$ (D) Preeti Bharati $^{3} \cdot$ Lone Badstue $^{4}$ (D) Ashok Yadav 5}

Tahseen Jafry

t.jafry@gcu.ac.uk

Preeti Bharati

bharati.preeti@gmail.com

Lone Badstue

1.badstue@cgiar.org

Ashok Yadav

ashokkyadav1@gmail.com

1 Pandia Consulting, Teigelkamp 64, 48145 Münster, Germany

2 The Centre for Climate Justice, Glasgow Caledonian University, Glasgow G4 OBA, Scotland, UK

3 B-39, Rajul Township, Tilhari, Jabalpur, MP 482021, India

4 International Maize and Wheat Improvement Center (CIMMYT), Carretera México-Veracruz Km. 45, El Batán, Texcoco C.P. 56237, México

5 Ananya Finance, Ranchi, Jharkhand, India 